\title{
PEMBUATAN SEDIAAN PAREM DARI DAUN MENGKUDU (MORINDA CITRIFOLIA) DENGAN CAMPURAN BERAS, KENCUR, JAHE UNTUK LUKA BAKAR
}

\author{
Ayi Noer Afni Latifa1, Risa Kota Putra ${ }^{2 *}$, Farhan ${ }^{3}$ \\ 1,2,3 Sekolah Tinggi Ilmu Kesehatan Holistik Purwakarta \\ *Korespondensi: Jl. Veteran No. 272 Ciseureuh Purwakarta, Email: risakotaputra@yahoo.co.id
}

\begin{abstract}
ABSTRAK
Latar belakang: Tumbuhan yang berperan penting dalam menyembuhkan luka bakar ini adalah mengkudu (Morinda Citrifolia), yang digunakan untuk bahan parem yaitu bagian daunnya. Adapun bahan lainnya digunakan untuk membuat sediaan parem yaitu beras, jahe dan kencur. Beras itu khasiatnya untuk penghilang rasa panas di bagian luka yang terbakar, jahe khasiatnya untuk mengurangi peradangan dikulit, kencur khasiatnya untuk menghilangkan bekas luka bakar.
\end{abstract}

Tujuan: Penelitian ini bertujuan untuk menjelaskan proses pengolahan daun mengkudu menjadi sediaan parem dengan bahan campuran tepung beras, kencur dan jahe.

Metode: Metodologi yang digunakan dalam penelitian ini yaitu deskriptif kualitatif, dengan mengambil beberapa kumpulan jurnal dari penelitian sebelumnya serta observasi lapangan, dan wawancara kepada sepuluh orang warga masyarakat desa sawah kulon. Pembuatan sediaan ini menggunakan daun mengkudu sebagai bahan utama sebanyak $250 \mathrm{~g}$ dengan bahan campurannya menggunakan tepung beras $500 \mathrm{~g}$, kencur $10 \mathrm{~g}$, jahe $10 \mathrm{~g}$ dan air satu gelas $( \pm 250$ $\mathrm{ml}$ ). Proses pembuatan parem dalam penelitian ini dengan mencampurkan semua bahan dalam satu wadah hingga terbentuk adonan, lalu adonan tersebut dibentuk menjadi bulatan-bulatan pipih dengan masing-masing berat 4-7g.

Hasil: Hasil pengujian organoleptis terhadap parem yang dihasilkan selama tiga minggu menunjukan bahwa tidak ada perubahan yang signifikan meliputi bentuk, warna, bau maupun pertumbuhan jamur.

Simpulan: Parem yang dihasilkan dari daun mengkudu dan campuran tepung beras, kencur serta jahe dapat tahan selama tiga minggu.

Kata Kunci: Parem, Luka Bakar, Beras, kencur, jahe

\begin{abstract}
Background: Plants that play an important role in healing this burn is mengkudu (Morinda Citrifolia), which is used for parem ingredients of the leaves. The other ingredients used to make preparations parem of rice, ginger and Kaempferia galanga. Rice is a usefulness for heat dissipation in the burned wound, ginger properties to reduce inflammation in the skin, and kaempferia galanga to remove burns.

The aim: The aim of this research is to describe the process of processing into preparations parem of noni leaf with a mixture of rice flour, kaempferia galanga, and Ginger.

Methode: The methodology used in this research is descriptive qualitative, by taking some collection of journals from previous studies and from observations by interviews with ten people of Sawah Kulon Village. Preparation use noni leaves as a main ingredient as much as $250 \mathrm{~g}$ with material mixtures using rice flour 500g, kaempferia galanga 10g, ginger $10 \mathrm{~g}$ and a glass of water (at about $250 \mathrm{ml}$ ). The process of making parem in this research is by mixing all the ingredients in a container to form a dough, then the dough is formed into flat circles with each weighing between 4-7g.

Result: This research was conducted organoleptic tests for three weeks with the results showed that no significant changes occurred, from the shape, color, odor and mold growth.

Conclusion: Parem resulting from noni leaves and rice flour mixture, kaempferia and ginger can last for three weeks.
\end{abstract}

Keywords: Morinda citrifolia, Parem, Burns, rice, kaempferia galanga, Ginger 


\section{PENDAHULUAN}

Di desa Sawahkulon kecamatan Pasawahan, untuk membantu persalinan, pemijatan khususnya bagi anak kecil, dan juga pengobatan kecelakaan ringan, masih mengandalkan tenaga Paraji (dukun beranak). Paraji masih menggunakan obatobatan yang berasal dari alam salah satu obat yang digunakan yaitu parem.

Parem Mengkudu yang bentuknya padat banyak khasiatnya untuk pengobatan luar diantaranya mengatasi sakit badan, pasca melahirkan, keseleo, penghangat badan, dan luka bakar. Tumbuhan yang berperan penting dalam menyembuhkan luka bakar ini adalah mengkudu (Morinda Citrifolia), yang digunakan untuk bahan parem yaitu bagian daunnya. Adapun bahan lainnya digunakan untuk membuat sediaan parem yaitu beras, jahe dan kencur. Beras itu khasiatnya untuk penghilang rasa panas di bagian luka yang terbakar, jahe khasiatnya untuk mengurangi peradangan dikulit, kencur khasiatnya untuk menghilangkan bekas luka bakar.

Mengkudu

(Morinda citrifolia),memiliki kegunaan tradisional maupun modern, termasuk akar dan kulit batang (pewarna dan obat), batang (kayu api dan perkakas), daun dan buah (makanan dan obat). Penggunaan sebagai obat baik tradisional maupun modern, mencakup kondisi dan jenis penyakit, walaupun kebanyakan dari manfaat ini belum didukung secara ilmiah ${ }^{1}$.Secara tradisional daun segar mengkudu dipakai sebagai obat untuk patah tulang, luka sayat atau luka potong yang dalam, luka bakar dan nyeri².

Adapun penelitian sebelumnya tentang daun mengkudu untuk luka bakar yaitu "pengaruh pemberian topikal salep dengan bahan aktif madu dan ekstrak daun mengkudu terhadap penyembuhan luka bakar derajat II superfisial"3. Namun berdasarkan wawancara dengan masyarakat desa sawahkulon, masyarakat desamasih menggunakan sediaan parem sebagai obat luka bakar, karena sediaan parem mudah dibuat.

Berdasarkan latar belakang diatas, maka peneliti tertarik untuk membuat Tugas Akhir dengan judul "Pembuatan Sediaan Parem dari Daun Mengkudu
(Morinda citrifolia) dengan campuran beras, kencur, jahe untuk Luka Bakar".

\section{METODELOGI PENELITIAN}

Penelitian ini menggunakan metode penelitian deskriptif yaitu penelitian yang dilakukan untuk menggambarkan karakteristik suatu kelompok subyek tertentu ${ }^{4}$. Dengan melakukan pengumpulan data, (observasi) wawancara dengan masyarakat setempat dilapangan, selain itu menggunakan data study pustaka. Penelitian dengan metode wawancara dimaksudkan untuk mengetahui seberapa lus masyarakat mengenal tumbuhan sebagai bahan obat, dalam hal ini sebagai nara sumber yaitu beberapa masyarakat yang pernah menggunakan tumbuhan beras, kencur, jahe dan daun mengkudu sebagai bahan obat tradisional dan bagaimana masyarakat tersebut membuat ramuannya. Tumbuhan diatas yang akan dibuat berupa sediaan parem. Ada beberapa tahapan seperti pengumpulan bahan, penyiapan bahan yang bagus untuk di jadikan obat ramuan, dan pembuatan sediaan parem.

Subyek dalam penelitian ini adalah orang dewasa berjumlah 20 orang dengan usia 30 sampai 80 tahun dengan beragam pekerjaan, akan tetapi yang diutamakan paraji (Dukun beranak). Penyiapan bahanbahan yang berdasarkan hasil wawancara adalah Pembuatan sediaan parem dari daun mengkudu dengan campuran tepung beras, kencur, jahe. Beras sebelum di haluskan di rendam terlebih dahulu selama 1 jam, setelah itu di tiriskan hingga kering. Lalu dihaluskan dengan cara di blender, masukan dalam wadah. Daun mengkudu, kencur dan jahe di cuci hingga bersih, lalu haluskan dengan cara di tumbuk. Setelah semua bahan halus, masukan ke dalam wadah yang berisi tepung beras, campurkan dan aduk homogen hingga menjadi adonan. Kemudian dicetak bulatan pipih, keringkan di bawah matahari langsung.

Lokasi penelitian dipilih Desa Sawah kulon Rt01/01 kec. Pasawahan kab. Purwakarta, peneliti memilih daerah tersebut dengan alasan karena masih banyak terdapat masyarakat yang menggunakan tumbuhan tradisional 
sebagai obat, selain itu pengobatan tradisional merupakan upaya penyembuhan terhadap penyakit yang dilakukan berdasarkan kepercayaan secara turun temurun dengan menggunakan bahan alami yang tersedia dan mempunyai khasiat secara empiris maupun melalui perantara paraji (dukun beranak), walaupun pengobatan modern telah banyak didaerah tersebut namun hingga sekarang pengobatan dengan bahan alam masih tetap dipertahankan, peneliti juga ingin memperkenalkan kepada masyarakat lain tentang khasiat ramuan beras, kencur, jahe dan daun mengkudu sebagai obat untuk luka bakar.

\section{HASIL PENELITIAN}

\section{Hasil dari wawancara}

Pada penelitian ini dilakukan wawancara sebanyak 20 orang di Desa Sawah kulon Rt 01/01 kec. Pasawahan kab. Purwakarta, yang bertujuan untuk mengetahui apakah benar parem mengkudu digunakan sebagai pengobatan luka bakar.

\section{Bahan}

Bahan tambahan untuk pembuatan parem mengkudu diantaranya :

1. Daun mengkudu yang sudah tua ukurannya besar dan berwarna hijau pekat.

2. Beras putih yang didapat dari pasar.

3. Jahe yang didapat dari pasar.

4. Kencur yang didapat dari pasar.

\section{Alat}

\begin{tabular}{cccc}
\hline No & Nama Alat & Spesifikasi & Jumlah \\
\hline $\mathbf{1}$ & Alu & kayu & 1 \\
$\mathbf{2}$ & Lampu (kawaci eco LED) & Kaca & 1 \\
$\mathbf{3}$ & Blender (GMC) & Kaca & 1 \\
$\mathbf{4}$ & Sendok & Stainles & 1 \\
$\mathbf{5}$ & Baskom (PIONER) & Plastik & 1 \\
$\mathbf{6}$ & Nampan & plastik & 1 \\
\hline
\end{tabular}

Setelah mengetahui bahan dan alat yang digunakan untuk pembuatan parem mengkudu, dilakukan wawancara tentang khasiat sediaan parem mengkudu yang pernah dibuat ibu titi sebagai paraji membuat tumbukan ramuan beras, kencur, jahe dengan campuran daun mengkudu untuk mengobati luka bakar diperoleh hasil wawancara seperti berikut:
Pertanyaan : $\quad$ Tumbuhan apa saja yang digunakan di desa ini untuk mengobati luka bakar dan bagaimana proses pembuatannya?
Jawaban informan: Tepung beras, jahe, kencur, daun mengkudu semua bahan dicampurkan, tambahkan air sedikit sampai terbentuk adonan, di cetak bulat, dijemur, setelah kering lalu Di tambahkan air sedikit, lalu di balurkan ke kulit yang terkena luka bakar.

Parem daun mengkudu dibuat di desa sawah kulon kec. Pasawahan kab. Purwakarta dengan didampingi warga yang sudah di wawancarai dan di dapat hasil wawancara yang menerangkan bahwa bahan-bahan untuk pembuatan parem adalah tepung beras, kencur, jahe dan daun mengkudu.

\section{Hasil Sediaan}

Dari tepung beras sebanyak $500 \mathrm{~g}$, daun mengkudu $250 \mathrm{~g}$, kencur $10 \mathrm{~g}$, jahe10g, air $250 \mathrm{ml}$ dibuat parem berbentuk bulatan pipih dengan masingmasing per 1 keping parem yaitu $7 \mathrm{~g}$. 


\section{Sediaan pertama jadi}

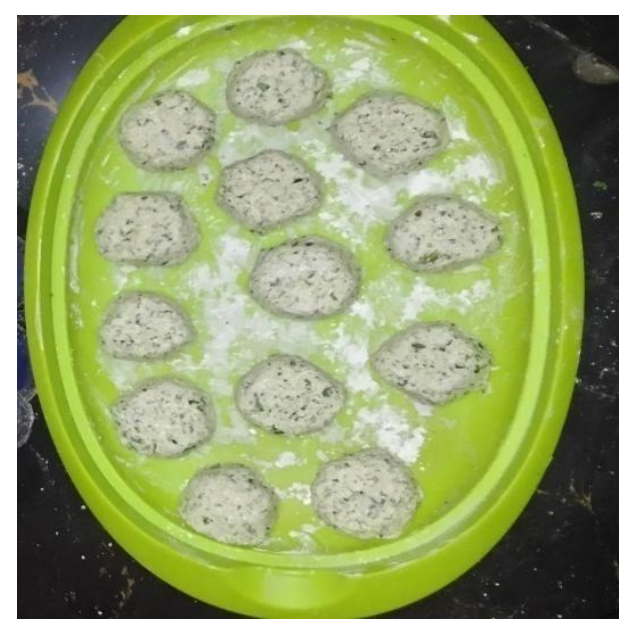

\section{PEMBAHASAN}

Dari hasil penelitian, pembuatan parem dari Beras, kencur, jahe dan daun mengkudu membutuhkan waktu selama dua hari yaitu penyiapan bahan dan proses pengeringan selama satu hari.

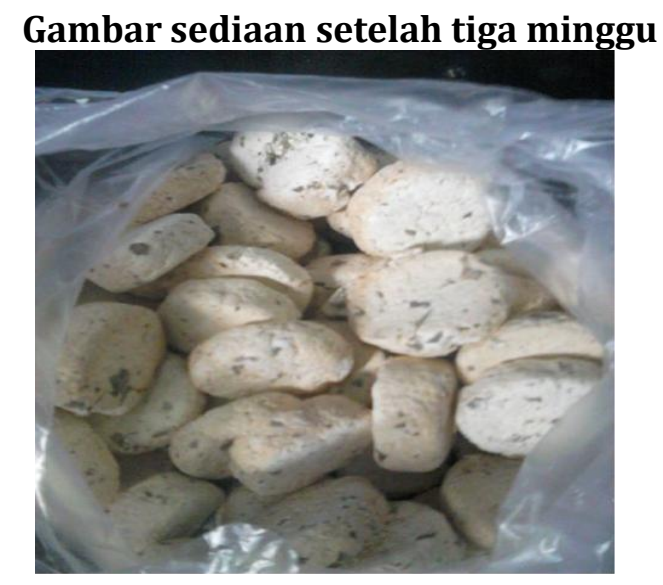

Penggunaan sediaan parem dari daun mengkudu dengan campuran beras, kencur, jahe caranyan dengan mengambil satu keping parem ditambahkan air sedikit dan dibalurkan kebagian kulit yang terkena luka bakar.

\section{SIMPULAN DAN SARAN}

\section{Simpulan}

Sediaan parem dari daun mengkudu yang ditambahkan dengan jahe sebagai penghangat, kencur sebagai penghilang bekas luka dan dengan bahan dasar parem berhasil dibuat, dengan organoleptik sediaan dengan warna sediaan putih kecoklatan dan totol-totol hijau serbuk

\author{
Keterangan : \\ Warna : putih, bercak hijau \\ Bau : khas parem \\ Bentuk : bulat pipih, retak-retak
}

\begin{abstract}
Dari hasil sediaan selama tiga minggu dan diuji organoleptis, hasil evaluasi sediaan yang sudah jadi yaitu sediaan bebrbentuk seperti kepingan uang logam, dengan warna putih kecoklatan bercak hijau dengan bau khas parem. Dan setelah tiga minggu sediaan disimpan tidak ada perubahan yang signifikan.
\end{abstract}

Keterangan :

Warna : putih kecoklatan, bercak hijau

Bau : khas parem

Bentuk : bulat pipih, retak-retak daun mengkudu. Dan sediaan parem dapat disimpan selama tiga minggu dengan keadaan fisik yang relatif tidak berubah. Sediaan parem dapat digunakan dengan cara mudah, hanya dengan mencampu rsedikit air dan dihaluskan lalu dioleskan keluka bakar.

\section{Saran}

Perlu adanya penelitian lebih lanjut untuk mengetahui kadar air parem agar proses pengadukan / pencampuran lebih homogen dan padat serta memiliki ketebalan yang sama. Serta perlu adanya literatur yang lengkap mengenai daun mengkudu sebagai obat luka bakar dan literatur mengenai sediaan parem. 


\section{DAFTAR PUSTAKA}

1. Nelson S.C., 2006. Species Profiles For Pacific Island Agroforestri, Morindo Citrifolia.

2. Rasal, V.P., Sinnathambi, A., Ashok, P., Yeshmaina, S. 2008. Wound Healing and Antioxidant Activities of Morinda citrifolia Leaf Extract in Rats. Iranian
Journal of Pharmacology \& Therapeutics. Vol: 7, No. 1. p. 49-52

3. Sugiyani. 2014. Pengaruh pemberian topikal salep dengan bahan aktif madu dan ekstrak daun mengkudu terhadap penyembuhan luka bakar derajat II, Universitas Hasanuddin : Makasar

4. Tim penyusun. 2016. Pedoman Penulisan Tugas Akhir Stikes Holistik. Purwakarta. 